\title{
Effects of pesticides used in soybean crops to the egg parasitoid Trichogramma pretiosum
}

\author{
Efeitos dos agroquímicos utilizados na cultura da soja ao parasitóide de ovos \\ Trichogramma pretiosum
}

\author{
Adeney de Freitas Bueno ${ }^{\mathrm{I}}$ Regiane Cristina Oliveira de Freitas Bueno \\ José Roberto Postali Parra ${ }^{\text {II }}$ Simone Silva Vieira ${ }^{\text {III }}$
}

\begin{abstract}
This research aimed to study the effects of different insecticides, herbicides and fungicides on eggs, larvae and pupae of Trichogramma pretiosum. The results showed that studied pesticides had different impact on $T$. pretiosum. Esfenvalerate 7.5 and spinosad 24.0 grams ha ${ }^{-1}$ were classified as harmfull (class 4) while clorfluazuron 10.0, methoxyfenozide 19.2, lactofen 165.0, fomesafen 250.0, fluazifop 125.0, glyphosate 960.0 (Gliz $^{\circledR}$ and Roundup Transorb ${ }^{\circledR}$ ), azoxistrobin + ciproconazol $60.0+24.0$, azoxistrobin 50.0 and myclobutanil 125.0 grams ha $^{-1}$ were chemicals classified as harmless to all imature T. pretiosum stages. All the other chemicals evaluated had different impact on T. pretiosum being classified from harmless (class 1) to harmful (class 4) varying the impact accordingly to the different parasitoid stage. Then, less noxious products should be chosen whenever possible to be used in a soybean IPM program.
\end{abstract}

Key words: selectivity, biological control, chemical control, integrated pest management.

\section{RESUMO}

Este trabalho teve como objetivo estudar os efeitos de diferentes inseticidas, herbicidas e fungicidas em ovos, larvas e pupas de Trichogramma pretiosum. Os resultados mostraram que os pesticidas estudados tiveram efeitos diferentes sobre $\mathbf{T}$. pretiosum. Esfenvalerato 7,5 e espinosade 24,0 gramas $\mathrm{ha}^{-1}$ foram classificados como nocivos (classe 4), enquanto que clorfluazurom 10,0, metoxifenozida 19,2, lactofem 165,0, fomesafem 250,0, fluazifope 125,0, glifosato 960,0 (Gliz ${ }^{\circledR} e$ Roundup Transorb $\left.{ }^{\circledR}\right)$, azoxistrobina + ciproconazole 60,0 +
24,0, azoxistrobina 50,0 e miclobutanil 125,0 gramas $\mathrm{ha}^{-1}$ foram classificados como seletivos (classe 1) para todas as fases imaturas de T. pretiosum. Todos os demais agroquímicos avaliados tiveram diferentes efeitos em T. pretiosum, sendo classificados de seletivo (classe 1) a nocivo (classe 4), variando o impacto de acordo com as diferentes fases do parasitóide. Portanto, produtos menos nocivos aos inimigos naturais devem ser escolhidos, sempre que possível, para serem usados em um programa de MIP-soja.

Palavras-chave: seletividade, controle biológico, controle químico, manejo integrado de pragas.

\section{INTRODUCTION}

Soybean, Glycine max, is an important crop for many countries around the world and the velvetbean caterpillar, Anticarsia gemmatalis, is one of its major pests (PANIZZI \& CORREA-FERREIRA, 1997). Some other caterpillars have also damage soybean plants. The soybean looper, Pseudoplusia includens, soybean webworm, Omiodes indicata, and some species from the genus Spodoptera such as the southern armyworm, S. eridania, have been also considered key pests by several soybean growers.

Among the egg parasitoids, those from the genus Trichogramma have been recognized as an important biological control agent of those pests for

IEmbrapa Soja, Londrina, PR, Brasil. Endereço para correspondência: Embrapa Arroz e Feijão, Rodovia GO, 462, km 12, Zona Rural, CP 179, 75375-000, Santo Antônio de Goiás, GO, Brasil. E-mail: adeney@cnpso.embrapa.br.

IDepartamento de Entomologia, Fitopatologia e Zoologia Agrícola, Escola Superior de Agricultura “Luiz de Queiroz”, Universidade de São Paulo (ESALQ/USP), Piracicaba, SP, Brasil.

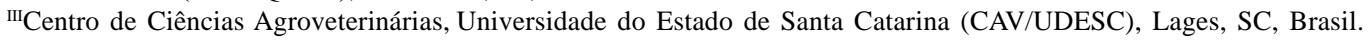


being worldwide distributed and capable of parasitizing eggs of a great diversity of pests from the order Lepidoptera (PRATISSOLI et al., 2004). Studies about Trichogramma have been carried out in more than 50 countries and inundative releases commercially done in around 32 millions of hectares every year (SMITH, 1996). Trichogramma have been also tested to control soybean pests (ZACHRISSON \& PARRA, 1998). This parasitoid is considered of high potential for controlling those species from the caterpillar complex that attacks soybean (BUENO et al., 2007) since Trichogramma parasitizes eggs from a great diversity of Lepidoptera pests.

Even though the biological control is of great importance, chemical control is still indispensable in agriculture. Nor just are the insecticides but also the fungicides and herbicides important tools for growers and crucial for them to succeed in their business. In this context, multiple tactics used in a compatible manner to add mortality to the natural biological control has been stressed in the integrated pest management (IPM) concept. Thus, the best chemicals to be used in the soybean-IPM are the ones effective against the pests and less noxious to the natural enemies. This association between biological and chemical control is essential in the agriculture and possible throughout the use of selective pesticides (SANTOS et al., 2006). To know the effects of the pesticides, normally used in soybean crops, above Trichogramma pretiosum is very important when choosing the chemical to be sprayed. Therefore, this research was carried out to study the selectivity of some common soybean insecticides, herbicides, and fungicides to the egg parasitoid T. pretiosum.

\section{MATERIAL AND METHODS}

The experiments were carried out in the Laboratory of Entomology at Embrapa Arroz e Feijão, Santo Antônio de Goiás, GO, Brazil and the strain of $\boldsymbol{T}$. pretiosum used was originally collected of parasitized eggs of $\boldsymbol{P}$. includens from soybean crops of Rio Verde, GO, Brazil. This strain was then raised on Anagasta kuehniella eggs, considered the best alternative host to keep this parasitoid colony in laboratory (GOMES \& PARRA, 1998). The insecticides, fungicides, and herbicides were mixed with water accordingly to the rates normally recommended to be used in soybean fields and considering the volume of 200 liters of mix per hectare. Thus, the following chemicals were tested: insecticides: clorfluazuron 10 and 35 grams ha- ${ }^{-1}$ (Atabron ${ }^{\circledR} 0.2$ and 0.7 liters ha ${ }^{-1}$ ); triflumuron 14.4 and 24 grams ha $^{-1}$ (Certero $^{\circledR} 30$ and 50 milliliters ha ${ }^{-1}$ ); alfacipermetrin 10 grams ha $^{-1}$ (Fastac $^{\circledR} 100$ SC 100 milliliters ha ${ }^{-1}$ ); zetacipermetrin 10 grams ha $^{-1}$ (Fury $^{\circledR}$ 400 CE 25 milliliters ha-1 $^{-1}$; methoxyfenozide 19.2 grams ha $^{-1}$ (Intrepid ${ }^{\circledR} 80$ milliliters ha $^{-1}$ ); lambdacialotrin 3.75 grams ha ${ }^{-1}$ (Karate Zeon ${ }^{\circledR} 250$ CS 15 milliliters ha-1); metomil 86 and 322.5 grams ha ${ }^{-1}$ (Lannate ${ }^{\circledR} 0.4$ and 1.5 liters ha ${ }^{-1}$ ); tiodicarb 56 grams ha $^{-1}$ (Larvin $^{\circledR} 70$ grams ha $^{-1}$ ); chlorpyrifos 240 grams ha $^{-1}$ (Lorsban $^{\circledR} 0,5$ liters ha $^{-1}$ ); lufenuron 7.5 grams ha $^{-1}$ (Match $^{\circledR} 150$ milliliters ha $^{-1}$ ); teflubenzuron 7.5 and 12 grams ha $^{-1}\left(\right.$ Nomolt $^{\circledR} 50$ and 80 milliliters ha $\left.{ }^{-1}\right)$; esfenvalerate 7.5 grams ha $^{-1}$ (Sumidan ${ }^{\circledR} 0.3$ liters ha ${ }^{-1}$ ); endosulfan 525 and 875 grams ha $^{-1}$ (Thiodan ${ }^{\circledR} 1.5$ and 2.5 liters ha ${ }^{-1}$ ); spinosad 24 grams ha $^{-1}$ (Tracer $^{\circledR} 50$ milliliters ha-1 ${ }^{-1}$; herbicides: clorimuron 20 grams ha $^{-1}$ (Classic $^{\circledR} 80$ grams ha $^{-1}$ ); lactofen 165 grams ha-1 $^{-1}\left(\right.$ Cobra $^{\circledR} 688$ milliliters ha $\left.^{-1}\right)$; fomesafen 250 grams ha $^{-1}\left(\right.$ Flex $^{\circledR} 100$ milliliters ha $\left.^{-1}\right)$; fluzifop 125 grams $^{-1}$ ha $^{-1}$ (Fusilade $^{\circledR} 1000$ milliliters ha $^{-1}$ ); glyphosate 960 grams ha-1 $^{-1}$ Gliz $^{\circledR} 2000$ milliliters ha $^{-1}$ ); glyphosate 972 grams ha- ${ }^{-1}$ (Roundup Ready 2000 milliliters ha-1); glyphosate 960 grams ha $^{-1}$ (Roundup Transorb ${ }^{\circledR} 1500$ milliliters ha ${ }^{-1}$ ); glyphosate 960 grams ha $^{-1}$ (Roundup Original ${ }^{\circledR} 2000$ milliliters ha $\left.{ }^{-1}\right)$; fungicides: tebuconazol + trifloxystrobin $200+100$ grams ha $^{-1}\left(\right.$ Nativo $^{\circledR} 500$ milliliters ha-1); azoxystrobin + cyproconazol $60+24$ grams ha $^{-1}$ (Priori Xtra ${ }^{\circledR} 300$ milliliters ha ${ }^{-1}$ ); azoxystrobin 50 grams ha $^{-1}$ (Priori $^{\circledR} 200$ milliliters ha $^{-1}$ ); myclobutanil 125 grams ha $^{-1}$ (Systhane ${ }^{\circledR} 500$ milliliters ha ${ }^{-1}$ ). Distillated water was used as the untreated.

Cardboard squares $\left(1 \mathrm{~cm}^{2}\right)$ with approximately $250 \mathrm{~A}$. kuehniella eggs each were offered for 24 hours to recently emerged $\mathbf{T}$. pretiosum females in vials. The number of females used was enough to guarantee close to $100 \%$ of parasitism. Then, these cards were transferred to vials and kept until the time after parasitism was sprayed with the treatments that were: 72 hours (eggs), 144 hours (larvae), 192 hours (pupae) (MANZONI et al., 2007). The cards having the parasitoids eggs, larvae and pupae were sunk into the treatment for five seconds being then left to dry for an hour to eliminate the excess of humidity. After that, the cards were placed in transparent plastic bags $(25 \mathrm{~cm} \mathrm{x}$ $5 \mathrm{~cm})$ and kept in controlled conditions $\left(25^{\circ} \pm 2^{\circ} \mathrm{C}, 70 \pm\right.$ 10\% RH, and 14:10 L:D). Four replications were used for each treatment in a random design. The parameter evaluated were the T. pretiosum emergency from the different treatments. The results were analyzed using PROC GLM procedure of the SAS program (SAS INSTITUTE, 2001) and means were separated by the test of Tukey $(P=0.05)$. The effect of the pesticides compared to the untreated was calculated by the following formula: $\mathrm{E}(\%)=(1-\mathrm{Vt} / \mathrm{Vc}) \cdot 100$, where $\mathrm{E}$ is the effect of the pesticide on the biological control agent 
being measured as the reduction of parasitism viability comparared to the untreated, Vt is the parasitism viability observed on each pesticide treatment and Vc is the parasitism viability observed on the control (untreated). The value E calculated for each pesticide treatment was classified accordingly to the International Organization of Biological Control (IOBC) where: class 1 - harmless $(\mathrm{E}<30 \%)$, class 2 - slightly harmful ( $30 \leq \mathrm{E} \leq 79 \%)$, class 3 - moderately harmful (80 $\leq \mathrm{E} \leq 99 \%)$ and class 4 - harmful $(\mathrm{E}>99 \%)$ (MANZONI et al., 2007).

\section{RESULTS AND DISCUSSION}

The benzoylphenylurea compounds evaluated in this research (clorfluazuron, lufenuron, teflubenzuron, and triflumuron) are examples of insect growth regulators (IGRs) chemicals that inhibit chitin synthesis. They are stomacal poisons and kill the target insects slowly, disturbing the chitin formation during molting (REYNOLDS, 1987). Methoxyfenozide, a substituted dibenzoylhydrazine, is an insecticide that functions by accelerating the molting process. It acts as an ecdysone agonist or ecdysonoid, substituting for the natural insect molting hormone, 20hydroxyecdysone (DHADIALLA et al., 1998). Those insecticides classified as IGRs are normally pointed out as harmless to natural biological control agents (SILVA et al., 1988; SANTOS et al., 2006). However, the results of this research show that the selectivity characteristic can not be taken for granted for all compounds from this group. The different IGR compounds were classified differently from harmless to harmful for the different parasitoid developmental stages (Table 1).

A. kuehniella eggs parasitized by $\boldsymbol{T}$. pretiosum sprayed with methoxyfenozide 19.2 grams ha $^{-1}$ had parasitism viability higher than $90 \%$, what was similar to the untreated at all tested parasitoid stages (Figures 1A, 1B, and 1C). Therefore, this treatment was one of the few insecticides classified as harmless (class 1) for all T. pretiosum immature stages (Table 1 ). These results showed that this insecticide at the tested rate is a good option to be used at a soybean-IPM program since it is harmless to all $\mathbf{T}$. pretiosum immature stages. Similar results were described by MANZONI et al. (2007) for tebufenozide, other insecticide with similar mode of action that also is grouped into the

Table 1 - Insecticide effect (E) on the reduction of Trichogramma pretiosum parasitism viability compared to the untreated (water) observed after the exposure of different developmental stages of the parasitoid to treatments.

\begin{tabular}{|c|c|c|c|c|c|c|}
\hline \multirow{2}{*}{ Treatment (a.i.) grams ha ${ }^{-1}$ grams 200L $^{-1}$ ) } & \multicolumn{2}{|c|}{-------Eggs-------- } & \multicolumn{2}{|c|}{-------Larvae-------- } & \multicolumn{2}{|c|}{-------Pupae------- } \\
\hline & $\mathrm{E}(\%)^{1}$ & Class $^{2}$ & $\mathrm{E}(\%)^{1}$ & Class $^{2}$ & $\mathrm{E}(\%)^{1}$ & Class $^{2}$ \\
\hline Clorfluazuron 10.0 & 1.48 & 1 & 0 & 1 & 28.50 & 1 \\
\hline Clorfluazuron 35.0 & 6.66 & 1 & 4.5 & 1 & 44.31 & 2 \\
\hline Triflumuron 14.4 & 93.39 & 3 & 100 & 4 & 3.84 & 1 \\
\hline Triflumuron 24.0 & 96.36 & 3 & 100 & 4 & 54.63 & 2 \\
\hline Alfacipermetrin 10 & 60.09 & 2 & 47.74 & 2 & 27.77 & 1 \\
\hline Zetacipermetrin 10 & 44.96 & 2 & 13.47 & 1 & 11.29 & 1 \\
\hline Methoxyfenozide 19.2 & 4.47 & 1 & 5.26 & 1 & 6.96 & 1 \\
\hline Lambdacialotrin 3.75 & 100 & 4 & 33.59 & 2 & 31.91 & 2 \\
\hline Metomil 86.0 & 44.86 & 2 & 50.61 & 2 & 52.33 & 2 \\
\hline Metomil 322.5 & 95.66 & 3 & 90.83 & 3 & 68.96 & 2 \\
\hline Tiodicarb 56.0 & 100 & 4 & 69.85 & 2 & 69.09 & 2 \\
\hline Chlorpyrifos 240 & 25.87 & 1 & 43.65 & 2 & 57.45 & 2 \\
\hline Lufenuron 7.5 & 58.78 & 2 & 15.23 & 1 & 37.73 & 2 \\
\hline Teflubenzuron 7.5 & 22.32 & 1 & 31.46 & 2 & 0 & 1 \\
\hline Teflubenzuron 12 & 46.95 & 2 & 38.72 & 2 & 20.25 & 1 \\
\hline Esfenvalerate 7.5 & 99.45 & 4 & 99.69 & 4 & 100 & 4 \\
\hline Endosulfan 525 & 38.2 & 2 & 87.25 & 3 & 22.87 & 1 \\
\hline Endosulfan 875 & 83.26 & 3 & 88.80 & 3 & 83.21 & 3 \\
\hline Spinosad 24 & 100 & 4 & 100 & 4 & 100 & 4 \\
\hline
\end{tabular}

${ }^{1} \mathrm{E}(\%)=(1-\mathrm{Vt} / \mathrm{Vc}) 100$, where $\mathrm{E}$ is the effect of the pesticide on the biological control agent being measured as the reduction of parasitism viability comparared to the untreated, Vt is the parasitism viability observed on each pesticide treatment and Vc is the parasitism viability observed on the control (untreated). ${ }^{2}$ Class: 1 . harmless $(\mathrm{E}<30 \%) ; 2$. slightly harmful $(30 \%<\mathrm{E} \leq 79 \%)$; 3 . moderately harmful $(80 \%<\mathrm{E} \leq 99 \%)$; 4. harmful ( $\mathrm{E}>99 \%)$. 


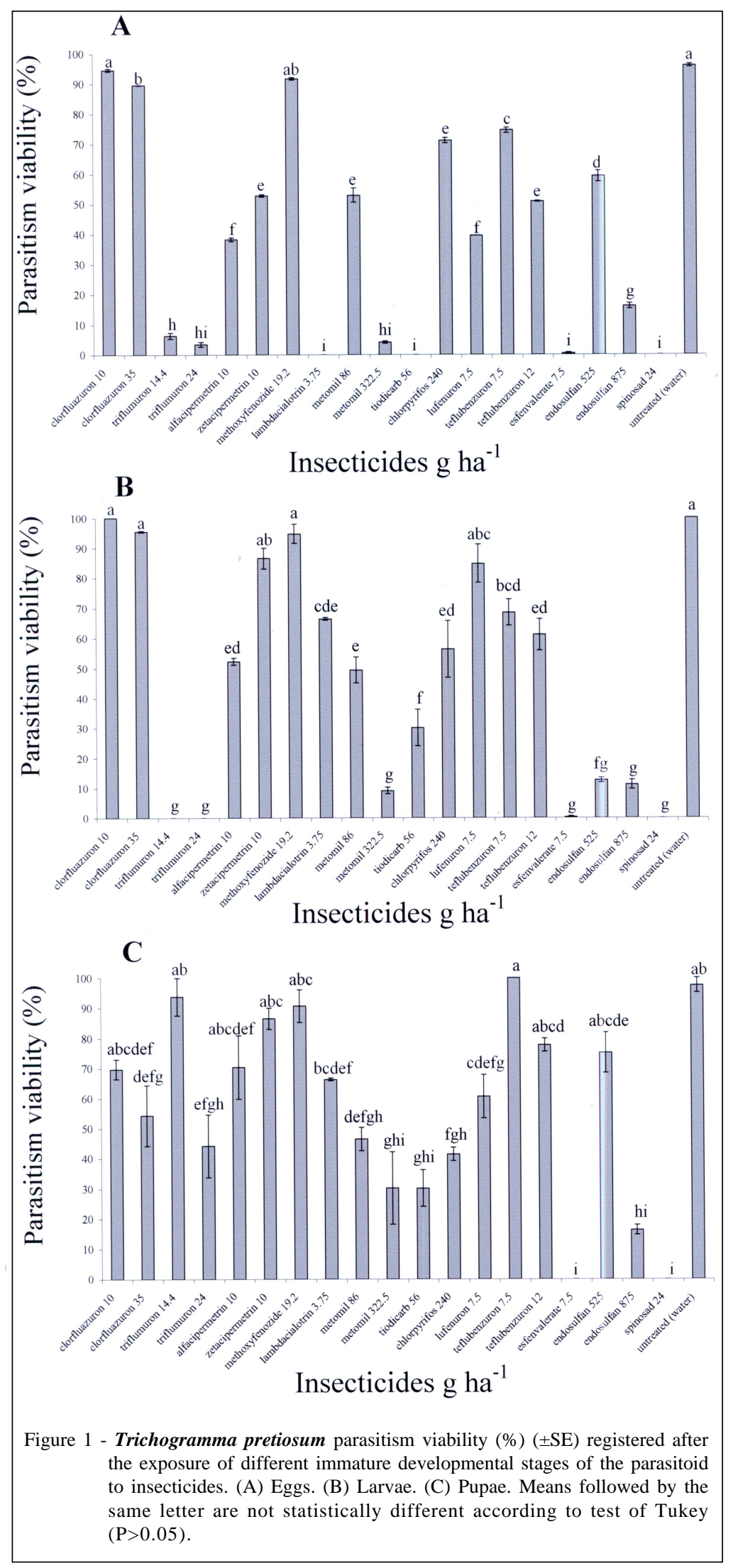

Ciência Rural, v.38, n.6, set, 2008. 
dibenzoylhydrazines. However, it is important to point out that methoxyfenozide 19.2 grams ha $^{-1}$ is normally sprayed to control A. gemmatalis. To control $\boldsymbol{P}$. includens outbreaks, methoxyfenozide rates up to 43.2 grams ha-1 might be required to reach acceptable pest control (BUENO et al., 2007). Thus, methoxyfenozide at higher rates also needs to be studied regarding to its selectivity to $\mathbf{T}$. pretiosum in future studies.

Clorfluazuron 10.0 grams ha ${ }^{-1}$ had similar results from methoxyfenozide, being also classified as harmless (class 1 ) to all $\mathbf{T}$. pretiosum immature stages (Table 1 ). The parasitism viability was higher than $90 \%$ for T. pretiosum eggs and larvae (Figures $1 \mathrm{~A}$ and $1 \mathrm{~B}$ ) and near to $70 \%$ to the pupae stage (Figure $1 \mathrm{C}$ ) being similar to the untreated. The parasitism was greater impacted by clorfluazuron at 35 grams ha ${ }^{-1}$. Its viability was significantly reduced for eggs and pupae of the parasitoid (Figures 1A and 1C) but not for the larva stage (Figure 1B). Even having a lower parasitism viability when $\boldsymbol{T}$ pretiosum was exposed to clorfluazuron at the higher rate, this treatment was still classified as harmless (class1) to eggs and larvae and slightly harmful (class 2) to pupae (Table 1). These results showed clorfluazuron affected very little $\boldsymbol{T}$. pretiosum development even when sprayed at the higher rate, what allows growers to increase insecticide rate accordingly to pest species or outbreak intensity in the field without harming the biological control performed by T. pretiosum. TAKADA et al. (2001) also described clorfluazuron as harmless to Trichogramma dendrolimi what reinforces the compatibility of using it together with biological control.

Lufenuron 7.5 grams ha-1 significantly reduced $\mathbf{T}$. pretiosum parasitism viability when this insecticide was sprayed on eggs and pupae of the parasitoid (Figure 1A and 1C), but it did not when sprayed on larvae (Figure 1B). This parasitism reduction was lower than $80 \%$ what led the insecticide to be classified as slightly harmful (class 2) to eggs and pupae and harmless (class 1) to larvae of the parasitoid (Table 1). This insecticide was also classified as slightly harmful (class 2) for T. pretiosum by ROCHA \& CARVALHO (2004) when adults of the parasitoid were exposed to host eggs previously sprayed with the insecticide. Similar results with lufenuron were described by HASSAN et al. (1998) who found a 34.8\% reduction in the parasitism of $\boldsymbol{T}$. cacoeciae when adults were exposed to the insecticide. These results showed that lufenuron is suitable to be used in IPM programs because it has been shown to cause low impact on Trichogramma species. However, the lufenuron has transovarian action on some insects what was demonstrated by PRATISSOLI et al. (2004) and ÁVILA
\& NAKANO (1999) for Spodoptera frugiperda and Diabrotica speciosa, respectively. This transovarian action was also observed for biological control agents. Even though not killing Chrysoperla externa adults, lufenuron significantly reduced its egg viability after adults of the predator had ingested the insecticide, what made it to be classified as harmful (class 4) to $\boldsymbol{C}$. externa adults (BUENO, 2001). The impact of lufenuron when it is ingested by $\mathbf{T}$. pretiosum adults still needs to be evaluated in future studies what will allow the insecticide impact to be better determined.

Teflubenzuron 7.5 grams ha $^{-1}$ significantly reduced parasitism viability when compared to the untreated when sprayed on T. pretiosum eggs and larvae (Figures 1A and 1B) and it was similar to the untreated when sprayed on $\boldsymbol{T}$. pretiosum pupae (Figure 1C), which is considered the most resistant stage to the action of insecticides (HASSAN, 1992). The increase in teflubenzuron rate to 12 grams ha-1 significantly reduced $\mathbf{T}$. pretiosum emergency when applied upon the egg stage (Figure 1A). Even though having this reduction, teflubenzuron was still classified as harmless (class 1) or slightly harmful (class 2) to $\boldsymbol{T}$. pretiosum immature stages (Table 1). Similar results were found by CARVALHO et al. (1994) that did not observe reduction in the number of parasitized eggs by $\boldsymbol{T}$. pretiosum due to IGR insecticides.

Triflumuron 14.4 and 24.0 grams ha ${ }^{-1}$ significantly reduced $\mathbf{T}$. pretiosum parasitism viability when applied on eggs and larvae of the parasitoid (Figures 1A and 1B). The pupa stage was the most resistant to the insecticide action since only the higher insecticide rate reduced parasitism viability when sprayed on this stage (Figure 1C). Therefore, triflumuron 14.4 and 24.0 grams $\mathrm{ha}^{-1}$ were moderately harmful (class 3) and harmful (class 4) to T. pretiosum eggs and larvae, harmless (class 1) and slightly harmful (class 2) to T. pretiosum pupae when applied at the lower and higher rate, respectively (Table 1 ). The pupa stage was the least impaired by the action of this insecticide. Similar results were found in the literature with other species of Trichogramma. CÔNSOLI et al. (2001) described the developmental time of Trichogramma galloi was not impaired when Anagasta kuehniella eggs previously parasitized was exposed to triflumuron. However, the T. galloi adults emerged from the treated eggs had a lower parasitism capacity. Then, other studies evaluating the insecticide effects on multiple generations of the parasitoid still need to be carried out to better classify the impact of the insecticide on a biological control program using T. pretiosum. 
The insecticides from the group of piretroids, which are commonly described as harmful to beneficial artropods (CAÑETE, 2005), were not always classified as harmful (class 4 ) in this research. Lambdacialotrin 3.75 grams ha $^{-1}$ was harmful (class 4) to T. pretiosum eggs and slightly harmful (class 2) for the other tested stages (Table 1). Alfacipermetrin and zetacipermetrin 10 grams ha ${ }^{-1}$ varied from harmless (class 1) and slightly harmful (class 2) accordingly to the stage tested (Table 1). Considering the parasitism viability, it was significantly reduced when the insecticides of this group were applied on the different stages of the parasitoid in most of the time (Figures $1 \mathrm{~A}, 1 \mathrm{~B}$ and $1 \mathrm{C})$. This is probably the reason that piretroids are generalized as harmful to most of the biological control agents. However, the selectivity must be carefully evaluated for all active ingredients of each compound and for the different biological control agent species.

Metomil 86 and 322.5 grams ha $^{-1}$ significantly reduced parasitism viability when applied above $\boldsymbol{T}$. pretiosum immature stages (Figures 1A, 1B, and 1C) receiving the classification of slightly harmful (class 2 ) when used at the lower rate and moderately harmful (class 3) when used at the higher rate except for pupae that the insecticide was classified as class 2 for both insecticide rates (Table 1). Tiodicarb 56 grams ha $^{-1}$ was classified as harmful (class 4) to T. pretiosum eggs and slightly harmful (class 2) to larvae and pupae of the parasitoid (Table 1). Chlorpyrifos 240 grams ha $^{-1}$ and endossulfan 525 and 875 grams ha $^{-1}$ reduced the parasitism viability when compared to the untreated, except for endossulfan at the lower rate when applied on T. pretiosum pupae (Figures 1A, 1B, and 1C). Chlorpyrifos was class 1, 2, and 2 and endosulfan 525 grams ha ${ }^{-1}$ class 2,3 , and 1 to T. pretiosum eggs, larvae, and pupae, respectively. Endossulfan 875 grams ha-1 was moderately harmful (class 3 ) for all T. pretiosum immature stages (Table 1). Similar results with endossulfan had been described by HOHMANN (1993). Esfenvalerate 7.5 and spinosad 24 grams ha ${ }^{-1}$ were harmful (class 4) to all immature stages of $\boldsymbol{T}$. pretiosum (Table 1). Negative results with spinosad on parasitoids from the genus Trichogramma had also been described by CAÑETE (2005). These products that are harmful to Trichogramma do not allow the association of both control methods and should be avoided when possible in an IPM program.

Fungicides and herbicides results showed that these products might also significantly reduce $\boldsymbol{T}$. pretiosum parasitism viability accordingly to the chemical and rate used (Figures 2A, 2B, 2C, 2D, 2E, and $2 \mathrm{~F})$. Among the herbicides clorimuron 20 and glyphosate (Roundup Ready) 972 grams ha-1 were classified as harmfull (class 4 ) for T. pretiosum eggs and harmless to the other parasitoid stages (Table 2). Glyphosate 960 (Roundup Original) was classified as slightly harmful (class 2) for eggs and harmless (class 1) for pupae of the parasitoid (Table 2). The other tested herbicides were harmless (class 1 ) for all T. pretiosum immature stages (Table 2). Herbicides with the same active ingredient and different impact on $\mathbf{T}$. pretiosum parasitism were already described in the literature that accordingly to GIOLO et al. (2005) is a consequence of different inert compound present in the herbicide formulations. Among the fungicides, tebuconal + trifloxystrobin $200+100$ grams ha $^{-1}$ was harmful, slightly harmful, and harmless to eggs, larvae, and pupae of $\boldsymbol{T}$. pretiosum, respectively. All other tested fungicide was harmless to all T. pretiosum immature stages (Table 2).

The results of this research showed that different pesticides had different impact on $T$. pretiosum being classified from harmful (class 4) to harmless (class 1) (Tables 1 and 2). Even fungicides and herbicides that are chemicals sometimes taken as harmless to beneficial arthropods were proven to have impact to the biological control being also classified as harmful (class 4) according to the product and rate used (Table 2). Thus, this study gives important results that will help to choose the best pesticide to be applied since products with the lowest impact on biological control are the most appropriated to be used in IPM programs. However, it is important to point out that this research was carried out under laboratory conditions where the parasitoid was submitted to the highest possible pesticide pressure, then, under field conditions pesticides might have their negative impact reduced because the biological control agents can benefit from natural shelters or avoid treated areas. Moreover, sunlight degradation plays an important role in the field that also helps to decrease the impact of pesticides on the beneficial arthropods observed in laboratory (ROCHA \& CARVALHO 2004). Therefore, the products classified as harmful (class 4) under laboratory conditions must also be tested on semi-field and field conditions in future studies to completely understand their impact on the biological control. 
A

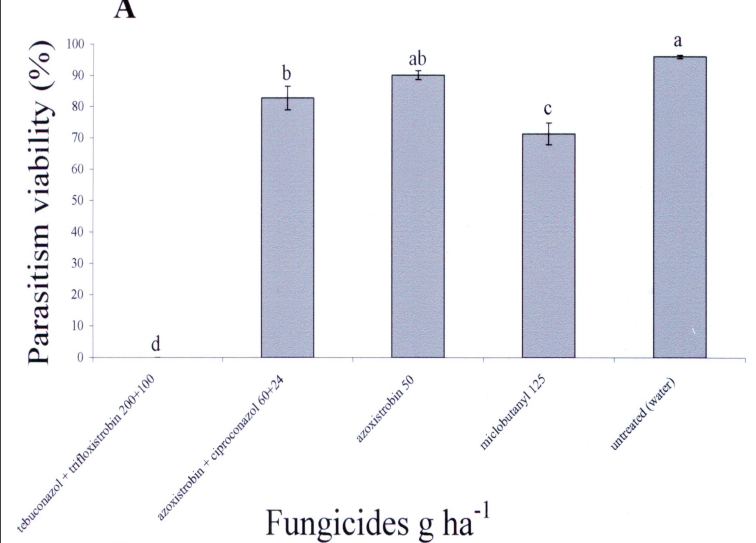

B

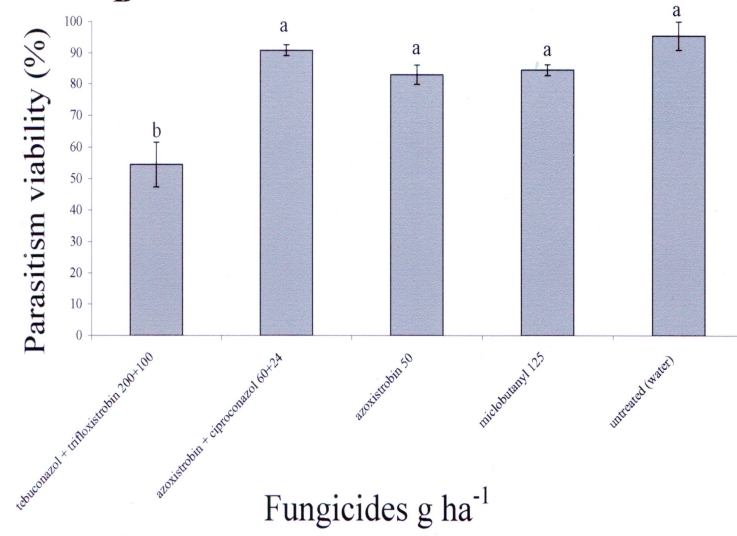

C

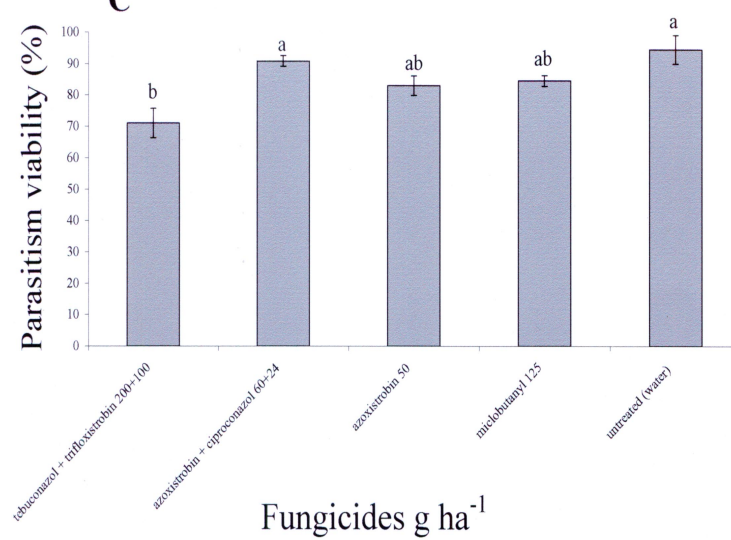

D

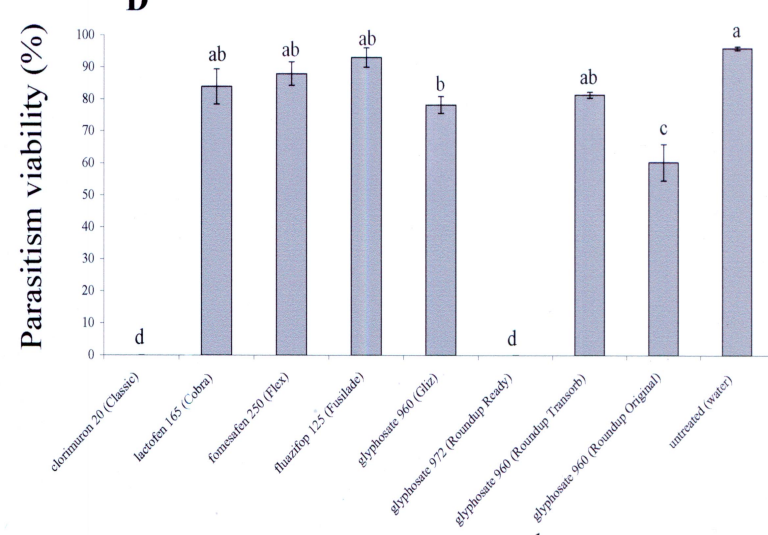

$\mathbf{E}$

Herbicides $\mathrm{g} \mathrm{ha}^{-1}$

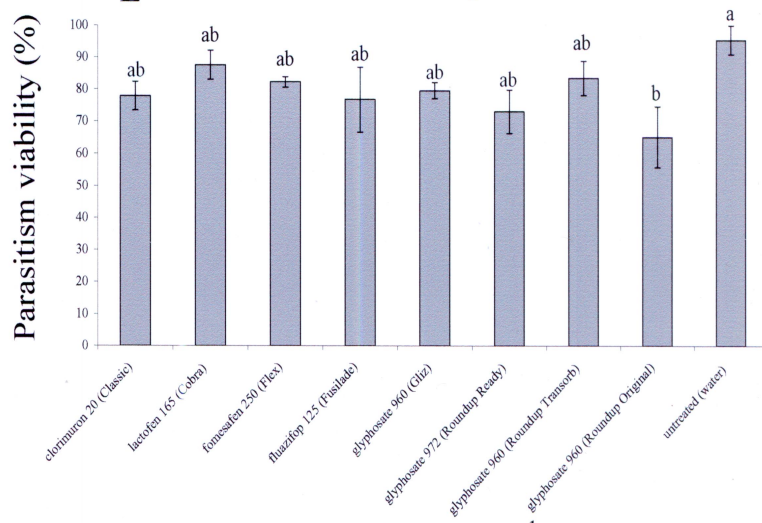

Herbicides $\mathrm{g} \mathrm{ha}^{-1}$

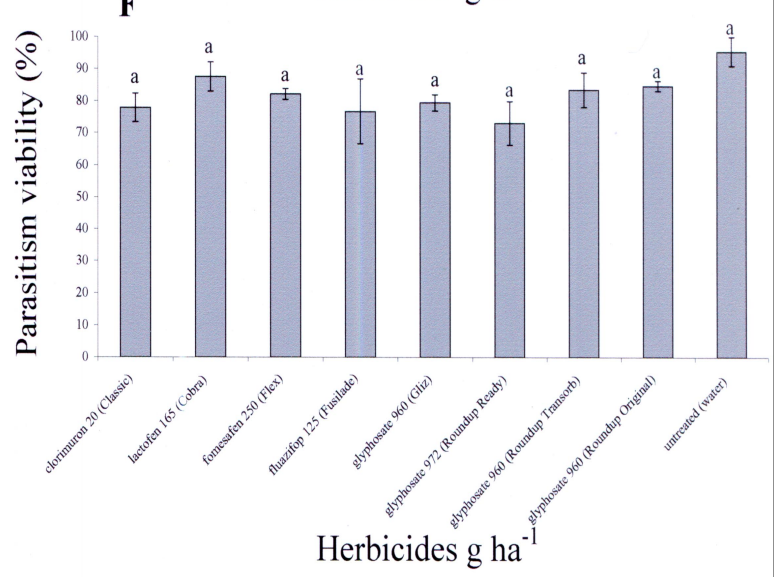

Figure 2 - Trichogramma pretiosum parasitism viability (\%) ( \pm SE) registered after the exposure of different immature developmental stages of the parasitoid to herbicides and fungicides. (A and D) Eggs. (B and E) Larvae. (C and F) Pupae. Means followed by the same letter are not statistically different according to test of Tukey (P $>0.05)$.

Furthermore, this research did not address the impact of pesticides above adults of T. pretiosum. Chemical control is known to have some negative effects on adults of different biological control agents. ROCHA \& CARVALHO (2004) showed that T. pretiosum parasitism is significantly reduced when adults are exposed to methoxyfenozide. CARVALHO et al. (2001) describe a reduction of $29 \%$ in T. pretiosum parasitism due to the action of triflumuron. Thus, future researches must also consider the impact of chemicals on adults to study the selecticity of different compounds. 
Table 2 - Herbicide and fungicide effect (E) on the reduction of Trichogramma pretiosum parasitism viability compared to the untreated (water) observed after the exposure of different developmental stages of the parasitoid to treatments.

\begin{tabular}{|c|c|c|c|c|c|c|c|}
\hline & \multirow{2}{*}{ Treatment (a.i.) grams ha ${ }^{-1}$ (grams 200L ${ }^{-1}$ ) } & \multicolumn{2}{|c|}{-------Eggs------ } & \multicolumn{2}{|c|}{------Larvae------ } & \multicolumn{2}{|c|}{------Pupae------ } \\
\hline & & $\mathrm{E}(\%)^{1}$ & Class $^{2}$ & $\mathrm{E}(\%)^{1}$ & Class $^{2}$ & $\mathrm{E}(\%)^{1}$ & Class $^{2}$ \\
\hline \multirow{8}{*}{ 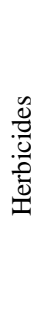 } & Clorimuron 20 (Classic) & 100 & 4 & 18.45 & 1 & 18.50 & 1 \\
\hline & Lactofen 165 (Cobra) & 12.60 & 1 & 8.29 & 1 & 8.30 & 1 \\
\hline & Fomesafen 250 (Flex) & 8.33 & 1 & 13.87 & 1 & 13.90 & 1 \\
\hline & Fluazifop 125 (Fusilade) & 3.12 & 1 & 19.54 & 1 & 19.50 & 1 \\
\hline & Glyphosate 960 (Gliz) & 18.52 & 1 & 16.74 & 1 & 16.70 & 1 \\
\hline & Glyphosate 972 (Roundup Ready) & 100 & 4 & 23.49 & 1 & 23.50 & 1 \\
\hline & Glyphosate 960 (Roundup Transorb) & 15.24 & 1 & 12.55 & 1 & 12.60 & 1 \\
\hline & Glyphosate 960 (Roundup Original) & 37.21 & 2 & 31.71 & 2 & 11.30 & 1 \\
\hline \multirow{4}{*}{ 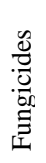 } & Tebuconazol+Trifloxystrobin 200+100 & 100 & 4 & 42.97 & 2 & 25.56 & 1 \\
\hline & Azoxistrobin + Ciproconazol $60+24$ & 13.87 & 1 & 4.87 & 1 & 4.87 & 1 \\
\hline & Azoxistrobin 50 & 6.18 & 1 & 13.05 & 1 & 13.05 & 1 \\
\hline & Myclobutanil 125 & 25.66 & 1 & 11.45 & 1 & 11.45 & 1 \\
\hline
\end{tabular}

${ }^{1} \mathrm{E}(\%)=(1-\mathrm{Vt} / \mathrm{Vc}) 100$, where $\mathrm{E}$ is the effect of the pesticide on the biological control agent being measured as the reduction of parasitism viability comparared to the untreated, Vt is the parasitism viability observed on each pesticide treatment and Vc is the parasitism viability observed on the control (untreated). ${ }^{2}$ Class: 1 . harmless ( $\left.\mathrm{E}<30 \%\right)$; 2 . slightly harmful $(30 \% \leq \mathrm{E} \leq 79 \%)$; 3 . moderately harmful (80\% $\left.\leq \mathrm{E} \leq 99 \%\right)$; 4. harmful $(\mathrm{E}>99 \%)$.

\section{ACKNOWLEDGMENTS}

This paper was approved for publication by the Editorial Board of Embrapa Soja as manuscript number 15/ 2007. The critical review from Dra. Lenita J. Oliveira and Dra. Beatriz S. Corrêa-Ferreira from Embrapa Soja are gratefully appreciated. Support from Embrapa Arroz e Feijão made this research on selectivity possible.

\section{REFERENCES}

ÁVILA, C.J.; NAKANO, O. Efeito do regulador de crescimento lufenuron na reprodução de Diabrotica speciosa (Germar) (Coleoptera: Chrysomelidae). Anais da Sociedade Entomológica do Brasil, v.28, n.2, p.293-299, 1999.

BUENO, A.F. Seletividade de inseticidas e acaricidas utilizados na cultura dos citros para Chrysoperla externa (Hagen, 1861) (Neuroptera, Chrysopidae) em condições de laboratório. 2001. 88f. Dissertação de Mestrado em Entomologia - Curso de Pós-graduação em Entomologia Agrícola, Universidade Estadual Paulista (UNESP), Jaboticabal, SP.

BUENO, R.C.O.F. et al. Sem barreira. Cultivar: Grandes culturas, n.93, p.12-15, 2007.

CAÑETE, C.L. Seletividade de inseticidas a espécies de Trichogramma (Hymenoptera: Trichogrammatidae). 2005. 106f. Dissertação (Mestrado em Zoologia) - Universidade Federal do Paraná, Curitiba, PR.

CARVALHO, G.A. et al. Seletividade de inseticidas reguladores de crescimento de insetos à Trichogramma pretiosum Riley (Hymenoptera: Trichogrammatidae). Anais da Sociedade Entomológica do Brasil, v.23 p.431-434, 1994.
CARVALHO, G.A. et al. Seletividade de alguns produtos fitossanitários a duas linhagens de Trichogramma pretiosum Riley,1879 (Hymenoptera: Trichogrammatidae). Ciência e Agrotecnologia, v.25, n.3, p.583-591, 2001.

CÔNSOLI, F.L. et al. Selectivity of insecticides to the egg parasitoid Trichogramma galloi Zucchi, 1988 (Hym., Trichogrammatidae). Journal of Applied Entomology, v.125, n.1-2, p.37-43, 2001.

DHADIALLA, T.S. et al. New insecticides with ecdysteroidal and juvenile hormone activity. Annual Review of Entomology, v.43, p.545-569, 1998.

GIOLO, F.P. et al. Seletividade de formulações de glyphosate a Trichogramma pretiosum (Hymenoptera: Trichogrammatidae). Planta Daninha, v.23, n.3, p.457-462, 2005.

GOMES, S.M., PARRA, J.R.P. The parasitization as tool for factitions host selection for Trichogramma galloi Zucchi and T. pretiosum Riley. Mittleillungen aus der Biologischen Bundesanstalt für Land-und Forstwirtschaft. Berlin, 1998. p.13-23.

HASSAN, S.A. Guidelines for the evaluation of side- effects of plant protection product on Trichogramma caoeciae. In: Internation Organization for Biological Control of Noxious Animals and Plants. Working Group “Pesticides and Beneficial Organisms”, 1992. p.18-39.

HASSAN, S.A. et al. The side-effects of pesticides on the egg parasitoid Trichogramma cacoeciae Marchal (Hym., Trichogrammatidae), acute dose-response and persistence tests. Journal of Applied Entomology, v.122, n.9-10, p.569-573, 1998.

Ciência Rural, v.38, n.6, set, 2008. 
HOHMANN, C.L. Efeito de alguns inseticidas sobre adultos de Trichogramma pretiosum RILEY. Anais da Sociedade Entomológica do Brasil, v.22, n.3, p.563-567, 1993.

MANZONI, C. G. et al. Seletividade de Agroquímicos utilizados na produção integrada de maçã aos parasitóides Trichogramma pretiosum Riley e Trichogramma atopovirilia Oatan \& Platner (Hymenoptera: Trichogrammatidae). BioAssay, v.2, n.1, p.111, 2007.

PANIZZI, A.R.; CORREA-FERREIRA, B. Dynamics in the insect fauna adaptation to soybean in the tropics. Trends in Entomology, v.1, p.71-88, 1997.

PRATISSOLI, D. et al. Ação transovariana de lufenuron (50 G/ L) sobre adultos de Spodoptera frugiperda (J. E. Smith) (Lepidoptera: Noctuidae) e seu efeito sobre o parasitóide de ovos Trichogramma pretiosum Riley (Hymenoptera: Trichogrammatidae). Ciência e Agrotecnologia, v.28, n.1, p.9-14, 2004

REYNOLDS, S.E. The cuticule, growth regulators and moulting in insects: the essential background to the action of acylurea insecticides. Pesticide Science, v.20, p.131-146, 1987.

ROCHA, L.C.D.; CARVALHO, G. A. Adaptação da metodologia padrão da IOBC para estudos de seletividade com Trichogramma pretiosum Riley, 1879 (Hymenoptera: Trichogrammatidae) em condições de laboratório. Acta Scientiarum Agronomy, v.26, n.3, p.315-320, 2004

SANTOS, A.C. et al. Seletividade de defensivos agrícolas aos inimigos naturais. In: PINTO, A. S. et al. Controle biológico de pragas na prática. 2006. p.221-227.

SAS INSTITUTE. SAS user's guide: statistics, version 8e. Cary, NC, 2001.

SMITH, S.M. Biological control with Trichogramma: Advances, successes, and potencial of their use. Annual Review of Entomology, v.41, p.375-406, 1996.

SILVA, M.T.B. da. et al. Avaliação de inseticidas sobre predadores das pragas da soja, em dez anos agrícolas, no Brasil. Trigo e Soja, n.96, p.3-16, 1988

TAKADA, Y. et al. Effects of various insecticides on the development of the egg parasitoid Trichogramma dendrolimi (Hymenoptera: Trichogrammatidae). Journal of Economic Entomology, v.94, n.6, p.1341-1343, 2001.

ZACHRISSON, B.A.; PARRA, J.R.P. Capacidade de dispersão de Trichogramma pretiosum Riley, 1879 para o controle de Anticarsia gemmatalis Hübner, 1818 em soja. Scientia Agricola, v.55, n.1, p.133-137, 1998. 